\title{
Transformando burocracias para financiar os mais pobres: a evolução do Pronaf Crédito Grupo B
}

L etícia M endonça

\section{Introdução}

Instituições financeiras, públicas ou privadas, não oferecem, tradicionalmente, serviços financeiros, principalmente crédito aos pobres. Essa aversão está relacionada aos riscos envolvidos nas operações, à falta de garantias, aos custos considerados elevados para a elaboração de contratos e projetos, às dificuldades de monitoramento e gestão das operações. No entanto, o crédito produtivo tem sido considerado um instrumento importante para a redução da pobreza, à medida que aumenta a liquidez financeira das famílias, propicia 0 capital indispensável para investimentos que podem aumentar a produção e reduzir riscos e, de certa forma, impulsiona a inserção dos produtores em mercados.

Considerando-se verdadeira a rigidez do sistema financeiro em trabalhar com os grupos mais descapitalizados, a criação do Programa Nacional de Fortalecimento da Agricultura Familiar (Pronaf), dentro da institucionalidade 
do Sistema Nacional de Crédito Rural (SNCR), é por si só um grande desafio. Com seus parâmetros e instrumentos baseados em um modelo de agricultura monocultora e de grande porte, diferenciado, portanto, das realidades da agricultura familiar, a iniciativa de criação do Pronaf, segundo o arcabouço legal do SNCR, faz com que deixe de ser apenas um programa de governo para assumir a condição de uma política pública de Estado, que apóia o desenvolvimento produtivo de famílias do campo de mais baixa renda.

Fundamentando-se na experiência de 10 anos de criação do Pronaf pode-se afirmar que, no âmbito dos seus gestores e implementadores, a construção e 0 aperfeiçoamento dessa política pública podem ser resumidos à difícil tarefa de buscar uma situação de recorrente equilíbrio entre o fim público, social e econômico do Programa e as lógicas de mercado das diferentes instituições financeiras que operam o crédito rural no País (bancos públicos comerciais e de investimento, bancos privados e cooperativas de crédito).

Mais concretamente, 0 aperfeiçoamento do Pronaf ao longo desses anos se dá por uma permanente dinâmica em prol de alterações normativas e adequação de arranjos operacionais com o objetivo de garantir acesso da agricultura familiar, em especial, dos mais pobres, ao crédito produtivo rural, sem que isso signifique abrir mão de agentes financeiros públicos e privados e de um aparato institucional típico da burocracia de Estado que regula o crédito rural no País. Se, por vezes, 0 desenho do SNCR se apresenta bastante estreito e pouco flexível para os fins pretendidos pelo Pronaf, por outras é uma conquista importante, sob vários aspectos (garantia de fontes de recursos, agentes operadores definidos com obrigatoriedade de aplicação, instituições normativas estabelecidas em lei) indispensável para 0 alcance e a continuidade do Programa enquanto uma política pública instituída pelos instrumentos de Estado.

Mais especificamente, no que condiz à criação e ao aperfeiçoamento da linha de microcrédito rural Pronaf Grupo B, foco deste artigo, o desafio é ainda maior. Em uma analogia, a criação dessa espécie de "inovação", quase considerada como "ousadia", situa o Pronaf no arcabouço legal rígido que estrutura o crédito rural no Brasil. Operacionalmente, 0 aperfeiçoamento dessa linha de crédito exige adaptações sucessivas e cumulativas em uma estrutura maior e mais pesada como a do SNCR. Substituir a obrigatoriedade do projeto técnico pela adoção da proposta simplificada, instituir ou não os Conselhos Municipais e Estaduais de D esenvolvimento Rural Sustentável (CMD RS e CED RS $)^{1}$ - como mediadores obrigatórios do acesso ao crédito -, assumir os riscos das operações ou transferi-las aos agentes financeiros, isentar os bancos das garantias ou deixá-las de livre negociação entre as partes são questões surgidas durante o processo de construção do Pronaf Grupo B. E todas vão sendo enfrentadas, com seus ônus e bônus, ao longo da concretização de uma política pública de microcrédito produtivo que alcance as famílias mais pobres da agricultura familiar do meio rural brasileiro e, ao mesmo tempo, não abra mão de ser reconhecida pelos instrumentos que estruturam e regulam o crédito rural no País.

Em face do exposto, este artigo tem como objetivo central apresentar o desenvolvimento institucional do Microcrédito Produtivo Rural Pronaf Grupo B, de sua criação, em 2000, até o momento atual. 
Espera-se, com isso, recuperar a visão dessa linha de crédito enquanto política pública em processo de aperfeiçoamento, trazendo, assim, elementos que permitam qualificar e situar melhor a discussão sobre os avanços desde a sua criação, além de identificar os atuais pontos de fragilidade. Pela forma como vai-se redesenhando, para onde caminha o microcrédito produtivo Grupo B? O que foi perdido e o que se ganhou nessa trajetória? Q uais são os desafios atuais e quais os pontos já superados? Em suma, espera-se que este trabalho possa trazer a visão de como 0 Pronaf Grupo B está sendo construído e vem-se desenvolvendo como política pública de microcrédito rural no aparato estatal. Essa construção institucional do Pronaf Grupo B adquire especial importância, pois, longe de ser um mero emaranhado de normas que findam em si mesmas, a institucionalidade reflete-se na ponta, potencializando e limitando comportamentos dos agentes operadores e das famílias agricultoras.

0 presente artigo encontra-se estruturado da seguinte forma. Na primeira parte é feito um breve resumo histórico do Pronaf, enfatizando as mudanças ocorridas na política de crédito diante do progressivo reconhecimento, pelo Programa, da diversidade da agricultura familiar. D estaca-se também o papel dos Grupos segundo a lógica do Pronaf, mostra-se onde está situado o Pronaf Grupo B na estrutura maior, e como se dá a distribuição dessas familias agricultoras nas cinco regiões do País. Em seguida, faz-se um resgate do processo de criação da linha de crédito Pronaf B, sua evolução nos normativos do próprio Pronaf e a gradual transformação, ainda em curso, numa linha de microcrédito produtivo orientado por meio do Programa Agroamigo, desenvolvido em parceria com o Banco do Nordeste. Na terceira parte são apresentados dados sobre o desempenho do crédito Grupo B, como número de operações e montantes aplicados por Plano de Safra. Por fim, são discutidas as lições aprendidas nessa trajetória, bem como pontuados os desafios a serem enfrentados pelo Pronaf Grupo B, para que este possa contribuirna promoção da geração de renda e de maior qualidade de vida às famílias de baixa renda do meio rural.
"Longe de ser um mero emaranhado de normas que findam em si mesmas, a institucionalidade reflete-se na ponta, potencializando $e$ limitando comportamentos dos agentes operadores e das famílias agricultoras."

Vale destacar que o objetivo de fornecer um referencial descritivo de cada passo e da mudança institucional exigida para avançar com a linha Pronaf G rupo B junto ao público mais descapitalizado de agricultores familiares foi auxiliar a caminhada de outros formuladores de políticas públicas que buscam soluções para a operacionalização em maior escala de ações de microcrédito produtivo. Soluções 
essas que envolvem, geralmente, discussões sobre riscos, garantias, agentes operadores e metodologia de oferta de crédito. Aos que optarem por uma leitura com menos detalhes, a última parte do artigo busca sistematizar a trajetória de implantação do Pronaf Grupo B, identificar tendências, aprendizados consolidados com relação a alguns temas e também pontuar diretrizes para futuros avanços.

\section{Diversidade da agricultura familiar no Brasil, o Pronaf e o público do Grupo B}

Como resultado das mobilizações dos agricultores familiares no II G rito da Terra Brasil $^{2}$, o Pronaf Crédito nasceu um pouco antes de o Pronaf surgir como programa, na safra 1995/ 1996, por meio da Resolução nº 2.191 do Conselho Monetário Nacional (CMN), de agosto de 1995. Na época, o crédito Pronaf resumia-se a uma linha única de financiamento com duas modalidades: custeio e investimento. A partir de então, pelo menos o segmento mais capitalizado da agricultura familiar começava a contar com crédito rural para financiar suas atividades produtivas. Parte significativa dos estabelecimentos familiares rurais, por sua vez, continuava excluída do acesso ao crédito.

O Pronaf tem sido apontado como um marco na história das políticas públicas para 0 campo, pois, pela primeira vez, houve tanto um reconhecimento por parte do Estado da especificidade da agricultura familiar ${ }^{3}$ quanto a implementação de um conjunto coerente de medidas para apoiar a atividade produtiva e o desenvolvimento dessas famílias.

Na sua criação em 1996, por meio do D ecreto Presidencial $n^{0} 1.946$, e como resultado de inúmeras mobilizações sociais desde 19924, definiu-se como objetivo do Pronaf "estimular o desenvolvimento rural tendo como fundamento o fortalecimento da agricultura familiar como segmento gerador de emprego e renda, de modo a estabelecer um padrão de desenvolvimento sustentável que vise ao alcance de níveis de satisfação e bem-estar de agricultores e consumidores, no que se refere às questões econômicas, sociais e ambientais, de forma a produzir um novo modelo agrícola nacional." (MAA, 1996). A pesar de outras ações ${ }^{5}$ terem sido promovidas naquele período, o Pronaf Crédito sempre foi a linha de atuação do Programa que se desenvolveu mais rapidamente e, conseqüentemente, tornou-se a mais visível ao público em geral.

Em 1997 ocorrem mudanças significativas no sentido de maior diversificação das políticas de crédito e de inclusão de novos segmentos da agricultura familiar. Uma greve de fome do Movimento dos Pequenos Agricultores do Rio Grande do Sul resultou no Pronaf Especial, linha de custeio destinada aos agricultores familiares de menor renda, a qual contava com subsídios na forma de desconto em valor fixo no pagamento em dia. Atualmente essa linha é conhecida como Pronaf Grupo C. Teve início, assim, no Pronaf Crédito, um processo de diferenciação das linhas de crédito, de reconhecimento da diversidade do público da agricultura familiar e da necessidade de construção de diferentes modalidades de financiamento e de distribuição de subsídios como forma de efetivamente alcançar as famílias produtivas do meio rural, de mais baixa renda.

A criação dos vários $G$ rupos do Crédito Pronaf surgiu em 1999. No plano técnico, essa segmentação se apoiou em uma série de estudos no âmbito do Projeto 
de Cooperação Técnica da O rganização das Nações Unidas para a Agricultura e a Alimentação (FAO)/ Instituto Nacional de Colonização e Reforma Agrária (Incra), alguns dos quais tomaram por base os dados do Censo Agropecuário 1995/ 1996. Esses trabalhos identificaram 4,1 milhões de estabelecimentos familiares no País e expuseram a diversidade desses empreendimentos em relação ao tamanho da propriedade, à tecnologia empregada e à renda. Apontaram ainda a existência de distribuição diferenciada no meio rural brasileiro, destacando-se a concentração de uma agricultura familiar mais capitalizada e estruturada nas regiões Sul e Sudeste, bem como uma agricultura descapitalizada e próxima aos níveis de pobreza nas regiões Norte e Nordeste do País.

Reconhecida e mensurada a diversidade de situações vivenciadas pela agricultura familiar no Brasil, os G rupos do Crédito Pronaf foram criados como forma de garantir tratamento diferenciado aos diferentes, tanto na canalização dos subsídios quanto na composição dos riscos das operações.

Os Grupos têm como critério definidor o nível de renda familiar bruta anual ${ }^{6}$ e, assim, a cada nível são oferecidas condições de financiamento diferenciadas ${ }^{7}$. (prazos, juros, limites, descontos por adimplência). D essa forma, os subsídios no crédito são distribuídos inversamente ao nível de renda, para que as famílias mais pobres possam receber condições de financiamento mais favoráveis. Com isso, os G rupos de renda mais elevada acessam o crédito Pronaf apenas nas condições próximas ao crédito rural da agricultura de maior escala.

Uma engenharia também específica relacionada aos $\mathrm{G}$ rupos se dá com o risco das operações. Nos Grupos de mais baixa renda ( $\mathrm{G}$ rupos $\mathrm{A}, \mathrm{A} / \mathrm{C}$ e $\mathrm{B}$ ), o risco das operações não é bancário, mas sim do Tesouro Nacional ${ }^{8}$. À medida que essas famílias vão construindo uma relação com o sistema financeiro, justamente por meio das operações Pronaf anteriores sem risco, se capitalizam e passam mais facilmente para os $\mathrm{G}$ rupos com risco bancário, acessando maiores valores e inserindo-se autonomamente no mercado de crédito rural. Assumir os riscos das operações iniciais sem dispensar a relação com 0 agente financeiro é uma estratégia importante do crédito Pronaf. Ao mesmo tempo que permite, de modo imediato, empréstimos para as famílias de mais baixa renda e alcança a pobreza, gradativamente, com a construção de um histórico de experiências positivas dessa ordem, possibilita a superação da "assimetria de informação" típica de situações de exclusão social e insere no sistema financeiro uma outra percepção sobre as possibilidades de negócios com esse público.

Toda a lógica do crédito segmentado em Grupos do Pronaf consiste, portanto, em fazer com que as familias enquadradas nos $G$ rupos de mais baixa renda possam, a partir do acesso ao financiamento e sua inversão produtiva, elevar os rendimentos e, conseqüentemente, ascender a um Grupo mais capitalizado. Neste Grupo, ainda que percam em subsídios, via taxas de juros ou descontos de adimplência, terão como estímulo a possibilidade de acessar um volume maior de recursos e ainda, em maior ou menor proporção paraalguns segmentos, de utilizar outros produtos ofertados pelos agentes financeiros, que passam a ver parte desse público como cliente.

A té a safra 2006/ 2007, o Pronaf constituía-se de seis Grupos com as características resumidas no quadro a seguir. 
Quadro 1: Grupos do Pronaf e caracteństicas de enquadramento Safra 2006/ 2007

\begin{tabular}{|c|c|}
\hline Grupus & Caracteristica para enquadramento \\
\hline$A \in A / C$ & 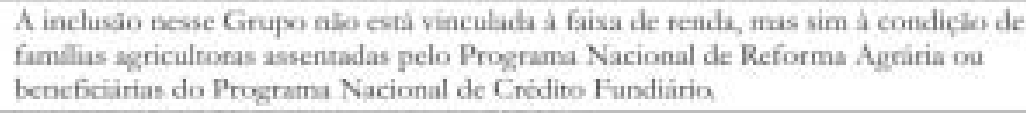 \\
\hline B & Familias com renda bruta anazl de até RS 3 mil \\
\hline C & Farnilias com nenda bruta anal acima de RS 3 mil até RS 16 mil \\
\hline D & Familias com renifa bruta anaal axima de 8516 mil até $\mathrm{F5}+5$ mil \\
\hline $\mathrm{B}$ & 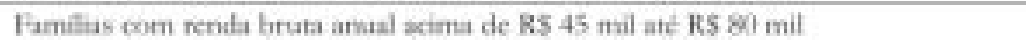 \\
\hline
\end{tabular}

A caracterização geral de agricultura familiar e a estratificação em G rupos estão institucionalmente determinadas em resoluções do Conselho Monetário Nacional (CMN). Essas resoluções também estabelecem a D eclaração de Aptidão ao Pronaf (DAP), um documento que classifica as famílias como agricultoras, enquadrando-as nos Grupos do Pronaf. A DAP constitui instrumento obrigatório para acesso ao crédito Pronaf, sendo normatizada por meio de portaria ministerial e emitida por instituições governamentais e não-governamentais credenciadas pelo Ministério do D esenvolvimento Agrário (MDA), em sua maioria sindicatos, movimentos rurais ${ }^{9}$ e empresas de assistência técnica. A participação da sociedade civil organizada no processo de identificação do público do Programa garante maior legitimidade, controle e comprometimento social da operacionalização do crédito.
Embora na atual segmentação do crédito Pronaf o Grupo B represente apenas uma das seis classificações possíveis, é o grupo ao qual pertence a maior parte dos estabelecimentos familiares rurais do País. A Secretaria da Agricultura Familiar do Ministério do D esenvolvimento Agrário (SAF/ MDA), em 199910, realizou a estimativa do público do Pronaf B, a partir dos dados dos estudos FAO / Incra. Segundo essas informações, as famílias do Grupo B representariam cerca de $50 \%$ do total de estabelecimentos da agricultura familiar do País, ou seja, um montante próximo a dois milhões. Além disso, os dados revelaram que esse contingente estava presente em todas as regiões, porém com uma concentração expressiva em torno de 75\% na Região Nordeste (Tabela 1).

Considerando-se a expressividade do público do Grupo B no total de

\section{Tabela 1: Estabelecimentos Pronaf B por região do País}

\begin{tabular}{l|r}
\hline Região & Grupo B \\
\hline Norte & 133.740 \\
\hline Nordeste & 1.499 .537 \\
\hline Sul & 165.091 \\
\hline Sudeste & 198.382 \\
\hline Centro-O este & 39.931 \\
\hline Total & 2.036 .681 \\
\hline
\end{tabular}

Fonte: FAO/ INCRA 
estabelecimentos familiares e a situação de pobreza e fragilidade social inerente a essas famílias, toma-se fundamental e estratégica a necessidade de construção, no âmbito do Pronaf, de normas e procedimentos específicos para assegurar a esse público 0 efetivo acesso ao crédito e, ao mesmo tempo, estimular o interesse dos diversos agentes operadores da política (bancos, assistência técnica, sindicatos e movimentos) na promoção de ações inclusivas para essas famílias. A criação do Pronaf Grupo B e o seu desenvolvimento na estrutura normativa do Pronaf, na qual atualmente constitui uma seção específica, é o que será abordado no próximo tópico.

\section{Criação do Pronaf B e o aperfeiçoamento dos normativos ao longo dos Planos de Safra}

D esde sua criação, o Pronaf Grupo B tem passado por mudanças e aperfeiçoamentos significativos em quase todos os Planos de Safra ${ }^{11}$. No Anexo 1 há um quadro resumo detalhado sobre a evolução dos normativos, das regras de operacionalização, das fontes de recursos e dos agentes financeiros operadores do Pronaf G rupo B em cada Plano de Safra. A seguir, descrevemos e comentamos os princípios, os objetivos e o impacto mais imediato de algumas dessas mudanças.

Da safra 2000/ 2001 à safra 2002/ 2003: a criação e consolidação da linha de crédito Pronaf Grupo B no Nordeste

O crédito Pronaf G rupo B surgiu em 10 de agosto de 2000, por meio da Resolução no 2.766 do Conselho Monetário Nacional (CMN), no bojo de uma discussão interministerial sobre a criação de ações não assistencialistas voltadas às famílias rurais de baixa renda da Região Nordeste. Em seu primeiro ano, na safra 2000/2001, a linha de investimento tinha um valor máximo de empréstimo da ordem de $\mathrm{R} \$ 500$, com juros de $1 \%$ ao ano e bônus de adimplência de $40 \%$ sobre cada parcela paga em dia, sendo destinada a famílias com renda bruta anual de até $\mathrm{R} \$ 1,5$ mil.

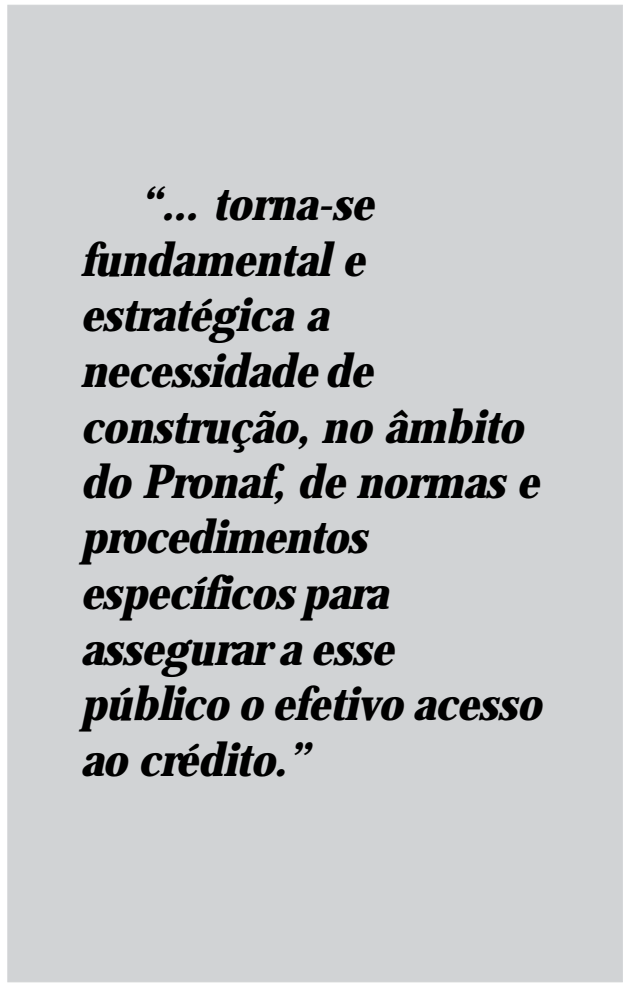

O princípio contido nesse bônus, que suscita acalorados debates até hoje, era não apenas estimular a adimplência, mas também realizar uma transferência de renda a essas famílias que empregam bem 0 financiamento. Transferência essa que, no caso do Pronaf Grupo B, tem como condicionalidade o emprego dos recursos em uma atividade produtiva, ou seja, a renda transferida pelo bônus se transforma em ativos de produção. Além disso, 0 bônus tornava 0 crédito de mais fácil 
pagamento. Diante dessa constatação, estimulava 0 acesso de famílias que jamais haviam obtido qualquer financiamento e que receavam endividar-se com o banco.

Buscando estimular a ascensão entre os Grupos, havia também a lógica de limitar o número de operações do Grupo $B$ em apenas três. Assim, após esse teto de operações, a família teria que contar com um incremento de renda que lhe permitisse alcançar as linhas de crédito do Grupo C. Posteriormente, como se verá mais à frente, esse entendimento teria de ser revisto em face de uma realidade mais complexa e obstáculos de emancipação de caráter mais estrutural, tal qual a questão fundiária.

Um outro ponto que merece destaque é a discussão do risco bancário das operações. Por se tratar de um público sujeito a vulnerabilidades características da situação de pobreza e da qual os agentes financeiros não possuem qualquer informação de comportamento bancário, o risco das operações do Pronaf Grupo B é assumido pelo Tesouro Nacional e não pelo agente financeiro operador. Essa tem sido, até hoje, a única forma para estimular os bancos a trabalharem com esse público. Como a lógica do Pronaf é de que as famílias possam se capitalizar e alcançar Grupos mais elevados (C, D, E), onde 0 risco das contratações já compete ao banco, a principal função das operações do Grupo B é criar uma relação entre as famílias e 0 agente financeiro capaz de facilitar a posteriorinserção em tais G rupos. Em outras palavras, espera-se que à medida que as familias agricultoras realizem as operações do Pronaf B, passem a ser conhecidas do agente financeiro, conquistando confiança para crédito de maiores valores e já com o risco bancário. Contorna-se assim o problema de "assimetria de informação", fazendo com que a transição dessas famílias para os Grupos C, D e E se torne uma conseqüência natural do histórico de adimplência das contratações anteriores, do Pronaf B.

Para a implantação da linha Pronaf Grupo B foi organizada, em Recife, uma "O ficina de Parceiros", envolvendo movimentos sociais, Banco do Nordeste, Ministério do Desenvolvimento Agrário, Conselhos Municipais de D esenvolvimento Rural Sustentável, empresas estaduais de Assistência Técnica e Secretários executivos do Pronaf ${ }^{12}$. Como resultados desse trabalho surgiram o Manual de Operações de Crédito do Programa Nacional de Fortalecimento da Agricultura Familiar (Pronaf Grupo B) e a portaria de credenciamento das instituições para a emissão da D eclaração de Aptidão ao Pronaf. O Manual O peracional estabelecia o formulário simplificado de "Proposta de Crédito", que futuramente alimentaria um banco de dados para avaliação das aplicações ocorridas. Pela portaria ministerial foram atribuídos aos Conselhos Municipais de Desenvolvimento Rural Sustentável (CMDRS) ou ao Conselho Estadual de Desenvolvimento Rural Sustentável (CED RS) a análise e 0 encaminhamento das propostas de crédito do Pronaf Grupo B para os bancos.

Definidos os instrumentos de operacionalização, o Banco do Nordeste foi 0 único agente financeiro que se interessou, na época, em atuar com a linha. As contratações para obtenção do crédito começaram a ocorrer em outubro de $2000^{13}$. Um intenso processo de mobilização, envolvendo reuniões em vários Estados e uma forte integração entre Federações de Trabalhadores da Agricultura (Fetag), empresas estaduais de Assistência Técnica, secretários executivos estaduais do Pronaf e Superintendências 
do Banco do Nordeste garantiu, ainda no ano de 2000, a contratação de 48.222 operações. Na safra 2000/ 2001, o período foi fechado com 52.442 contratos e R\$ 26.076.576,96 aplicados.

A safra 2001/ 2002 marca um momento de consolidação da linha. Muitos CMD RS foram criados e, nesse ambiente, as contratações quase triplicaram, passando para 154.481 e um total de $\mathrm{R} \$ 77.110 .900,13$ financiados. No Manual de Crédito Rural (MCR), duas únicas alterações ocorreram. 0 prazo de reembolso da linha foi reduzido, passando de dois anos, com um ano de carência, para um ano, com seis meses de carência, estimulando-se, dessa forma, um retorno mais rápido dos recursos. Passa a constar também no normativo a autorização para utilização de proposta simplificada de crédito em substituição ao projeto técnico mais complexo e obrigatório pelo próprio MCR nas demais operações de crédito rural.

A safra 2002/ 2003 retorna com 0 prazo de dois anos para pagamento do crédito, com um ano de carência, e formaliza, no próprio $\mathrm{MCR}$, a obrigatoriedade da participação do processo de operacionalização do crédito aos Conselhos Municipais de D esenvolvimento Rural Sustentável (CMD RS) ou, no caso desses não existirem, aos Conselhos Estaduais de Desenvolvimento Rural Sustentável (CEDRS). A partir de então, tornava-se uma exigência não apenas ministerial, mas do normativo do crédito rural e sujeita à fiscalização do Banco Central , encaminhar à análise do CMD RS todas as propostas do Pronaf Grupo B. Somente após cumprida essa etapa, eram encaminhadas ao agente financeiro para contratação.

A té a safra 2002/ 2003 a ampliação do crédito Grupo B estava condicionada ao incremento do número de CMDRS, pois, na prática, o CEDRS não conseguia funcionar como seu substituto. Além disso, o prazo de encaminhamento das propostas até a contratação durava meses devido à exigência da reunião do Conselho, que só se realizava quando se acumulava um número significativo de propostas.

As aplicações na safra 2002/ 2003 registram, portanto, um leve declínio de quase 15 mil contratos e cerca de $\mathrm{R} \$ 7,2$ milhões, em comparação à safra anterior. O número de operações passa para 139.760 e o valor fica em $R \$ 69.838 .802,76$. Por trás dessa queda, pode-se especular alguns fatores, tais como operações em prazo de carência, impossibilitando o acesso da mesma família ao crédito, e dificuldades burocráticas de acesso das famílias do Grupo B, ainda mais empobrecidas; eleições, que no final de 2002 influenciaram as discussões nos Conselhos Municipais; ou até mesmo a mudança na forma de atuação do MDA, priorizando o fomento e a capacitação de conselhos de âmbito territorial.

\section{Safra 2003/ 2004: desburocratização do acesso, o "boom" das contratações e a chegada do Pronaf Grupo $B$ à Região Norte}

Importantes mudanças ocorrem com os normativos do Plano de Safra 2003/ 2004, determinadas pela priorização do Pronaf pelo novo governo. No que se refere ao G rupo B, a renda de enquadramento passou de $\mathrm{R} \$ 1,5$ mil para R\$ 2 mil, e o limite de financiamento dobrou de valor, passando de $\mathrm{R} \$ 500$ para $\mathrm{R} \$ 1$ mil. Era consenso que 0 valor anterior muito reduzido do Pronaf B limitava as possibilidades de aplicação da linha e, dessa forma, inviabilizava inversões que pudessem ter maior impacto na estrutura produtiva das famílias. $\mathrm{O}$ valor do bônus de adimplência também sofreu alterações: 
reduziu-se em termos percentuais, de $40 \%$ para $25 \%$, mas em termos absolutos passou de um valor máximo de até $\mathrm{R} \$ 200$ para até $\mathrm{R} \$ 250$.

A safra 2003/2004 tentou avançar sobre o problema da falta de interesse da Assistência Técnica e Extensão Rural (ATER), pública e privada, em trabalhar com o público do Grupo B. Por conta disso foi inserida a possibilidade de financiamento da assistência técnica no próprio crédito. A té 3\% do valor financiado passava a ter a possibilidade de destinação ao pagamento de serviços de ATER. Assim, 0 bônus de adimplência que, em termos absolutos, passara a alcançar maior valor, funcionaria como um mecanismo indireto de financiamento estatal dos serviços de ATER para essas famílias de baixa renda. Uma ferramenta de controle social das prestadoras de serviço de ATER foi também instituída. Por meio da Portaria da Secretaria da Agricultura Familiar (SAF) atribuiu-se ao CED RS a competência para credenciar, descredenciar e monitorar as empresas prestadoras.

A queda no número de contratações na safra 2002/ 2003 e as crescentes reclamações por parte das representações dos movimentos rurais quanto ao excesso de burocracia na operacionalização da linha levou à criação de um G rupo de Trabalho para desburocratização do crédito Pronaf B, no segundo semestre de 2003. Reuniram-se representantes do Ministério do Desenvolvimento Agrário, Ministério da Fazenda e Banco do Nordeste para propor soluções aos principais entraves do acesso ao crédito. Algumas medidas de simplificação exigiam apenas mudanças de procedimentos internos do banco, outras precisariam passar pela aprovação do Conselho Monetário Nacional. O resultado desse trabalho foi a publicação da Resolução n 3.150 do CMN, em novembro de 2003.

Nessa resolução foram quatro os pontos tratados. 0 primeiro deles foi a autorização aos agentes financeiros para isentar as operações do Grupo B de garantia de terceiros, passando a ser suficiente a garantia pessoal do tomador de crédito. Sendo o Tesouro Nacional 0 responsável pelo risco da operação, a exigência de garantias das operações do Grupo B tornara-se, na prática, uma mera formalidade. Embora houvesse alguns casos raros de exigência de garantias reais, 0 aval era majoritariamente 0 instrumento mais utilizado. Contudo, esses avais em geral eram feitos entre famílias que não se conheciam, ou ainda com desconhecimento dos mutuários sobre essa relação. Não serviam, portanto, para gerar comprometimento no bom emprego dos recursos, mas tão somente um vínculo que, algumas vezes, resultava na inadimplência de apenas um dos envolvidos, o que colocava em situação de dívida até mesmo os demais que pagaram corretamente 0 seu crédito ${ }^{14}$.

Uma segunda mudança importante trazida pela Resolução no 3.150 foi o fim da obrigatoriedade de mediação do CMDRS para encaminhamento das propostas de crédito. Havia casos de conselhos "prefeiturizados", em que 0 crédito só saía para aqueles que fossem aliados dos grupos no poder. Além disso, alguns municípios não tinham acesso ao crédito porque não dispunham de Conselhos, os quais só podiam ser criados por ato do poder municipal. A ausência de CMDRS, por exemplo, era um dos fatores que impediam a expansão do crédito na Região Norte. Já nessa fase, 0 Banco da Amazônia e o Banco do Brasil mostravam-se dispostos a começar a operar a linha. A inexistência de Conselhos 
em algumas regiões do País constituía um fator limitante.

A terceira mudança instituída pela Resolução no 3.150 recaiu sobre o papel da D eclaração de Aptidão ao Pronaf (DAP). Esta passa a ser considerada instrumento suficiente de comprovação da relação da família agricultora com a terra. Antes dessa medida, a exigência de título de propriedade ou contrato de arrendamento formalizado em cartório excluía do acesso ao crédito um número significativo de famílias de baixa renda.

Finalmente, a quarta mudança promovida pelo Grupo de simplificação facilitava 0 acesso das famílias aos recursos financiados. Nas operações do Pronaf G rupo B estava dispensada a apresentação dos comprovantes relativos aos bens adquiridos, exceto quando referentes a máquinas, equipamentos, embarcações e veículos financiados nas modalidades de crédito grupal ou coletivo, de valor superior a R \$ 5 mil. A exigência da entrega dos comprovantes fazia com que as famílias assumissem um custo de transação elevado, ao terem que enfrentar os gastos do deslocamento até as agências.

As medidas de simplificação tiveram efeitos imediatos no total das aplicações. As contratações dobraram, alcançando 333.555 famílias atendidas. Um total de R\$ 327.010.055,39 foi emprestado. A safra 2003/ 2004 iniciava uma fase de massificação do crédito Pronaf Grupo B. A desburocratização operacional da linha tinha gerado resultados e promovido 0 acesso de famílias de baixa renda ao crédito rural. No âmbito do controle social, iniciase 0 processo de emissão de DAP em modelo eletrônico. As DAPs assim emitidas passam a ser encaminhadas para o site do Pronaf, facilitando a consulta por parte da sociedade.
Tais iniciativas tornaram a operacionalização do Grupo B menos onerosa e mais simples ao agente financeiro. Em maio de 2004, o Banco da Amazônia começa a operar na Região Norte, e ainda na safra 2003/ 2004 são realizadas 14.535 operações, representando R $\$ 14.448 .365,00$ em recursos aplicados. O Banco do Brasil, por sua vez, realiza algumas operaçõesteste, operando regularmente apenas em agosto de 2004, já na safra 2004/ 2005.

$\quad$ "Havia casos
de conselhos
'prefeitunizados', em
que o crédito só saía
para aqueles que
fossem aliados dos
grupos no poder.
Além disso, alguns
municípios não tinham
acesso ao crédito
porque não dispunham
de Conselhos, os quais
só podiam ser criados
por ato do poder
municipal."

Safra 2004/ 2005: novas fontes de recursos e a expansão do Pronaf $B$ para todas as regiões do País

Com o sucesso da simplificação das regras de acesso ao crédito e agentes financeiros dando início às operações, os recursos do Tesouro Nacional mostravamse ainda insuficientes para as novas demandas. A safra 2004/ 2005 vai, 
portanto, buscar novas fontes para atender ao incremento da procura. Essas novas fontes de financiamento, porém, teriam que continuar a isentar os agentes financeiros do risco bancário.

Em agosto de 2004, após negociações com os ministérios da Fazenda e da Integração - este último, devido a sua responsabilidade sobre os Fundos Constitucionais de Financiamento ${ }^{15}$ - foi publicada a Medida Provisória ${ }^{0} 205^{16}$, que atribuía o risco das operações do Pronaf Grupo B não ao agente financeiro, mas ao Fundo Constitucional por ele operado. Essa mudança legal fez com que, tornava-se crescente e saltava de cerca de R\$ 25 milhões, na época da criação da linha, para, atualmente, mais de R\$ 500 milhões. Sem precisar arcar com o risco das operações, os bancos tiveram mais estímulo para trabalhar com operações do Grupo B utilizando recursos dos Fundos Constitucionais de Financiamento. Esses Fundos, ao longo dos anos anteriores, tinham parte expressiva dos seus recursos não aplicados em inversões produtivas e, por conseguinte, destinados a operações do mercado financeiro.

Vale destacar que, mesmo sem continuar a responder pelos riscos das

\section{Tabela 2: Pronaf Grupo B: fontes de financiamento em cada Plano de Safra}

\begin{tabular}{|c|c|c|c|c|c|c|}
\hline Ane & FNE & FNO & OGU & Tot: & & \%Tesouro \\
\hline $2000 / 2001$ & & - & RS $26,076,567,96$ & RS & $26,076.567,96$ & $100,00 \%$ \\
\hline $21901 / 21002$ & & - & R.5 $77,110,900,13$ & R5 & $77,110,9001,13$ & $100,00 \%$ \\
\hline $21902 / 21003$ & & + & R5 $69838.802,76$ & Rs & $69,838,8012,76$ & $100,00 \%$ \\
\hline $21903 / 2144$ & & 100000 & R5 $3271000,054,39$ & Rs & $327,010055,39$ & too,, $00 \%$ \\
\hline $2004 / 2005$ & RS $267.609 .912,37$ & Rs $5 .+15.130,72$ & RS $45.508 .915,40$ & RS & $358.593 .958,49$ & $23,85 \%$ \\
\hline $2005 / 21066$ & RS $521.444 .755,44$ & ItS $795.273,92$ & R5 $33.107,431,49$ & RS & $555.347,460,85$ & $5,96 \%$ \\
\hline Tixtal & R5 $789,114,6667,81$ & H.5 $6.210 .404,64$ & R3 $618,651.673,13$ & RS 1 & $.413,976,745,58$ & $43,75 \%$ \\
\hline
\end{tabular}

Fonte: SAF/ MDA

na prática, fosse criado um funding para a linha em todas as regiões de Fundos Constitucionais de Financiamento (Norte, Nordeste e Centro-O este), possibilitando, assim, que os recursos do Tesouro Nacional fossem destinados apenas às regiões Sul e Sudeste, nas quais os Fundos não operam.

Como demonstra a Tabela 2, a Lei alcançou os resultados esperados, fazendo com que a participação dos recursos do Tesouro Nacional no Pronaf B passasse de $100 \%$ do valor aplicado para menos de $6 \%$ do montante na safra 2005/ 2006. Ao mesmo tempo, o total aplicado operações do G rupo B, existe um estímulo a mais para um bom emprego desses recursos quando a fonte é um Fundo Constitucional de Financiamento. Uma vez que os bancos gestores desses fundos (Banco do Brasil, Banco do Nordeste, Banco da Amazônia) recebem, a título de remuneração pela administração dos recursos, um percentual fixo sobre 0 patrimônio líquido do Fundo, o mau emprego desses valores em aplicações de elevada inadimplência representa uma descapitalização dos Fundos, resultando na diminuição da remuneração auferida pelo banco. 
Com recursos sem riscos, garantidos pela nova lei, o Banco da Amazônia e 0 Banco do Nordeste começaram a operar o Grupo B majoritariamente com recursos dos Fundos Constitucionais de Financiamento. No caso do Banco do Brasil, divergências de interpretação da nova lei frente à Lei do Fundo Constitucional de Financiamento do Centro-O este, ainda sem solução, fez com que a operacionalização da linha pelo Banco do Brasil se desse somente em setembro de 2004 e integralmente com os recursos do Tesouro Nacional. Com os três agentes operando em todo o Brasil, ocorria assim a nacionalização da linha de crédito Pronaf $\mathrm{B}$.

Mudanças no Manual de Crédito Rural (MCR) também ocorreram para o Grupo B na safra 2004/2005. A composição da renda de enquadramento deixava de exigir a obrigatoriedade de que fosse proveniente integralmente das atividades desenvolvidas no estabelecimento rural. De uma renda bruta anual de enquadramento de até R\$ 2 mil, apenas 30\% teriam que necessariamente provir de atividades rurais agrícolas ou não agrícolas do estabelecimento rural; o restante poderia ter origem em outras ocupações. Tratava-se de uma medida de maior adequação dos normativos à realidade das estratégias de sobrevivência dessas famílias, as quais obtêm parte de sua renda da venda de mão-de-obra a terceiros ou pelo desenvolvimento de atividades temporárias fora do meio rural.

Uma alteração no MCR foi a formalização da garantia pessoal como suficiente para operações do Grupo B. Instituída em caráter sugestivo e autorizativo pela Resolução $n^{0} 3.150$, torna-se obrigatória no Plano de Safra 2004/ 2005. Uma outra modificação operacional importante foi a dispensa da dupla assinatura (sindicato e empresa de ATER) para acesso à DAP do Grupo B. Essas famílias não precisavam mais arcar com os custos de duas assinaturas de instituições distintas para ter aDAP validada. Simplificava-se assim o acesso à DAP para esse Grupo ${ }^{17}$.

Com mais recursos, novos agentes operadores em todo o Brasil e alguns avanços no MCR, as aplicações do Pronaf G rupo B na safra 2004/ 2005 continuaram a crescer. Foram 358.456 contratos realizados e R\$358.593.958,49 em montante aplicado. Com o aumento expressivo do público atendido pela linha, as propostas de mudanças para aperfeiçoamento do crédito do Grupo B começaram a mudar de enfoque. Passa-se a considerar não tanto a maneira como expandir o acesso ao crédito, mas, principalmente, como qualificar e potencializar o emprego desses recursos.

Nessa direção, em novembro de 2004 foi assinado um Termo de Cooperação Técnica entre o Ministério do D esenvolvimento Agrário e o Banco do Nordeste do Brasil. O objetivo do termo era desenvolver uma nova metodologia de aplicação do crédito Pronaf Grupo B: começava a nascer o Agroamigo e a primeira experiência de transformação do Pronaf Grupo B em uma linha de microcrédito produtivo orientado.

\section{Safra 2005/ 2006: 0 Pronaf Grupo B enquanto microcrédito produtivo nural e a experiência do Agroamigo}

As mudanças nos normativos na safra 2005/ 2006 são fortemente influenciadas pelo novo Projeto BNB e MDA. Foi criada uma seção específica para o Pronaf G rupo B, integrada ao capítulo do Pronaf no MCR, e suas regras foram agrupadas em um só trecho, não ficando mais dispersas ao longo das várias seções do 
Pronaf. Adicionalmente, pela primeira vez, a linha de crédito Pronaf $B$ passa a ser referida no MCR também pelo termo microcrédito produtivo rural, o que sinaliza uma importante mudança de concepção. Vencida a barreira do excesso de burocracia no acesso ao crédito, 0 novo desafio era garantir mais qualidade e assistência na aplicação dos recursos. A transformação do Pronaf Grupo B em microcrédito produtivo orientado dá, portanto, importantes passos nessa safra.

D o ponto de vista teórico, o microcrédito produtivo é a concessão de empréstimos de pequeno valor para atividade produtiva em geral, realizado com 0 uso de metodologia específica. Já o crédito produtivo orientado, segundo Manzon (2006), tem como principal característica 0 relacionamento capacitado, efetivo, freqüente entre a instituição de microcrédito e o empreendedor, por meio da figura do agente de crédito. As informações derivadas dessa interlocução devem subsidiar ainda a decisão sobre 0 valor e as condições do empréstimo, aumentando progressivamente os recursos emprestados a cada operação.

A norma anterior do Pronaf B, contudo, criava limitações a esse mecanismo mais flexível de aplicação de gestão dos recursos que caracteriza o microcrédito. Em especial, a regra antiga limitava 0 número de operações em três e fixava um valor máximo de R\$ 1 mil para cada uma delas. Diante dessas regras, havia um estímulo para que as operações fossem realizadas sempre no teto, o que garantiria 0 acesso ao valor máximo de $\mathrm{R} \$ 3$ mil ao final dos três financiamentos permitidos. A nova forma de acesso, introduzida pelo Plano de Safra 2004/ 2005, incentivava 0 acesso ao crédito $B$ em valores menores e de acordo com as reais necessidades das famílias. Foi mantido o limite máximo de $\mathrm{R} \$ 3$ mil a ser acessado por família, embora a forma de dispor desse limite não seja mais de três operações, mas quantas forem necessárias até alcançar esse teto.

Para evitar que o resultado dessas mudanças fossem operações únicas de $\mathrm{R} \$ 3$ mil, fixou-se em R\$ 1 mil um valor máximo por operação. A partir disso, uma família do Grupo B poderia se valer do microcrédito produtivo rural de até R\$ 3 mil sem limites no número de operações e de formas muito variadas, por exemplo, em duas operações de $\mathrm{R} \$ 250$, duas de $\mathrm{R} \$ 500$ e uma de R\$ 1 mil.

Foi ajustado, ainda, de R $\$ 5$ mil para R\$ 10 mil o valor abaixo do qual se dispensava a apresentação ao agente financeiro de comprovantes relativos aos bens adquiridos. Essa mudança tinha impacto para as operações contratadas de forma coletiva ou grupal, quando esses montantes eram facilmente alcançados.

Um passo significativo nessa etapa de busca de mais qualidade na aplicação dos recursos deu-se com a implantação do projeto de microcrédito rural orientado junto ao BNB, pelo qual o banco passou a ofertar a linha Pronaf G rupo B a partir de assessores de crédito especialmente treinados e recrutados para esse trabalho. Essa nova metodologia de operacionalização do Grupo B tornou-se uma ação específica no banco, recebendo o nome de Programa Agroamigo. Ainda que nem todas as operações contratadas tenham sido feitas segundo a metodologia, os assessores treinados e dedicados exclusivamente à operacionalização da linha já provocaram um novo crescimento expressivo das contratações do Pronaf Grupo B nesse período. A safra 2005/ 2006 registrou 553.555 operações e alcançou 0 valor de $\mathrm{R} \$ 555.347 .460,85$ 
aplicados, sendo que cerca de 95\% desse valor foi aplicado pelo Banco do Nordeste.

O Banco do Nordeste já possuía uma experiência exitosa de microcrédito urbano denominada Crediamigo. O desafio do A groamigo seria adaptar essa metodologia para o meio rural onde, além de ser maior a dispersão geográfica dos clientes, o ciclo produtivo das atividades agrícolas é mais longo e, conseqüentemente, o giro dos recursos. Somados ao risco de mercado estão os riscos climáticos e de pragas, que costumam atingir todo um povoado (PARENTE, 2002).

\section{Programa Agroamigo}

O Agroamigo, programa de microcrédito rural desenvolvido pelo Banco do Nordeste em parceria com 0 MDA e a GTZ, tem como objetivo principal expandir 0 atendimento a agricultores de mais baixa renda, mediante a concessão de microcrédito produtivo e orientado. As principais inovações em relação ao trabalho desenvolvido com o grupo B são:

- Atendimento integral ao cliente por um profissional especializado: 0 assessor de crédito rural;

- Estudo prévio do mercado a ser atendido, com mapeamento de mercado e estruturação da demanda;

- Orientação e atendimento ao cliente em sua localidade, possibilitando 0 acesso ágil e simplificado ao crédito: busca-se a concessão de crédito em no máximo sete dias após o início do processo de contratação;

- Acompanhamento sistemático do cliente e do crédito, com contratação de créditos seqüenciais e gradativos, possibilitando a identificação das dificuldades e necessidades de outros serviços financeiros e bancários.
O Agroamigo adota a metodologia utilizada pelo Programa Crediamigo, programa de microcrédito produtivo desenvolvido pelo Banco do Nordeste na área urbana, com as devidas adaptações para o setor rural. Por meio de uma Organização da Sociedade Civil de Interesse Público (O scip), o Instituto Nordeste Cidadania, que atua na mesma área de abrangência do banco, são adotados os seguintes procedimentos:

- Os assessores de microcrédito rural executam as atividades de concessão de crédito, envolvendo a elaboração de cadastro de clientes, elaboração das propostas, proposta de crédito simplificada, acompanhamento e renovação do crédito;

- As atividades decorrentes do processo de concessão do crédito - deferimento, cadastramento, contabilização e outros serviços de retaguarda - são de responsabilidade da Agência do BNB.

0 assessor de crédito é um técnico agrícola (ou outra formação afim) oriundo da área onde vai atuar e que recebe treinamento específico necessário para trabalhar no Programa. Esse profissional realiza um mapeamento dos agricultores de baixa renda de sua área de trabalho, promove palestras informativas, realizalevantamentos socioeconômico e de mercado, orienta a elaboração de planos de negócios, criando uma relação de proximidade com os agricultores familiares que atende. Atualmente existem 350 assessores contratados.

A coordenação da execução das atividades desenvolvidas pelo assessor de microcrédito rural é atribuição do gerente de Suporte a Negócios, com destaque para as seguintes atividades:

- Selecionar, em conjunto com os assessores de microcrédito rural, os municípios priorizados para atuação; 
- Administrar o provimento de condições logísticas para o trabalho dos assessores: computadores, mesas, telefone, material de expediente, entre outros;

- Acompanhar as rotinas internas do processo de contratação das propostas encaminhadas pelos assessores de microcrédito rural, possibilitando agilidade na contratação;

- Realizar acompanhamento da produtividade da carteira de clientes do assessor de microcrédito rural;

- Participar da elaboração de roteiro mensal de deslocamento do assessor de microcrédito rural no atendimento aos clientes;

- Acompanhar a execução das atividades realizadas pelo assessor de microcrédito rural, mantendo o Instituto Nordeste Cidadania constantemente informado de qualquer dificuldade ou problema na execução das tarefas.

A té julho de 2006, o Agroamigo já respondia por $23 \%$ das operações do Pronaf B realizadas e já estava implantado em cerca de 29\% dos municípios da área de atuação do Banco. Ao final de 2007, esperava-se que todas as operações do Pronaf B junto ao Banco do Nordeste já se realizassem sob a metodologia do Agroamigo.

0 crescimento do número de operações da linha de microcrédito também impôs a necessidade de melhorias nos processos de gerenciamento das aplicações pelo próprio ministério. Para tanto, na safra 2005/ 2006, o MCR estabeleceu que a linha de crédito do Grupo B do Pronaf seria operacionalizada pelos agentes financeiros, em comum acordo com a Secretaria de Agricultura Familiar do Ministério do Desenvolvimento A grário (SAF/ MDA). D essa forma, foi assegurado respaldo legal para a SAF obter com os agentes financeiros operadores melhor acesso às informações das aplicações da linha.

\section{Safra 2006/ 2007: ampliação das possibilidades de um microcrédito produtivo orientado e início da integração com outros programas federais}

A safra 2006/ 2007 trouxe em seus normativos mais mudanças. A renda de enquadramento para o Grupo B, fixada em R\$ 2 mil, desde a safra 2003/ 2004, foi reajustada para $\mathrm{R} \$ 3$ mil. A idéia é que houvesse maior aproximação dessa faixa de renda com a utilizada por outros importantes programas federais de combate à pobreza ${ }^{18}$. Nesse período, todos os demais Grupos do Pronaf passam também por reajustes em suas rendas de enquadramento.

O valor máximo por operação fixado desde a safra 2003/ 2004 foi novamente apontado como insuficiente para aplicações produtivas de efeitos mais estruturantes, passando de R\$ 1 mil para R 1,5 mil. Constatado que questões estruturais e de solução de mais longo prazo, tal qual a concentração fundiária, impediam a ascensão de algumas famílias do G rupo B para o Grupo $\mathrm{C}$, mesmo após ter sido utilizado todo o limite de financiamento, o microcrédito produtivo Grupo B passou a não ter um teto máximo. D essa forma, as famílias do Grupo B passaram a ter direito a pleitear financiamento pela linha sempre que necessário, sem limite de número de operações, desde que cada uma delas não ultrapasse $\mathrm{R} \$ 1,5$ mil.

O bônus de adimplência, por sua vez, ficou restrito ao valor acumulado de até R\$ 4 mil. A família que acessar o Pronaf B após já ter financiado esse valor perde 0 direito ao bônus, mas continua acessando 
a linha. D essa maneira, o crédito Grupo B não exclui mais famílias que alcancem um teto de financiamento, porém, a partir de determinado valor, retira o instrumento de transferência de renda implícito no bônus, estimulando essas mesmas famílias a buscarem inversões produtivas capazes de gerar mais renda.

O utra mudança na safra 2006/ 2007 foi a maior flexibilização na aplicação dos recursos. Muitas vezes as famílias de baixa renda, em razão de uma seca, uma epidemia ou outra situação adversa, vêemse obrigadas a mudar os planos de aplicação do crédito. Em vez de adquirirem a vaca, como estava inicialmente proposto, investem em dois porcos. 0 MCR possibilitou que a proposta de crédito inclua uma lista de atividades nas quais as famílias poderiam investir os recursos. Evita-se, assim, que alguma operação do microcrédito Grupo B que tenha tido os recursos empregados de forma produtiva, eporvezes mais eficiente do que o estipulado inicialmente na proposta de crédito, seja considerada irregular ou que se exija a formalização de aditivo ao contrato.

Para que as famílias tenham ciência do direito aos serviços deATER para os quais são destinados 3\% do valor financiado, introduziu-se, por meio do MCR, a obrigatoriedade de que o percentual de ATER incluído na proposta somente seja financiado caso haja concordância explícita dos tomadores do crédito.

Duas tentativas de articulações com outras políticas públicas foram realizadas na safra 2006/ 2007 e incluídas nos normativos. A primeira é uma integração com o Programa Nacional de Biodiesel. $\mathrm{O}$ microcrédito produtivo rural $\mathrm{G}$ rupo $\mathrm{B}$, que sempre fora uma linha de investimento, passou a ser utilizado para financiamento de custeio da mamona, desde que essas famílias sigam o zoneamento agrícola e estejam integradas com empresas do Programa Nacional de Biodiesel.

Uma segunda tentativa de articulação do crédito Grupo B se deu com 0 Programa Nacional de Microcrédito Produtivo Orientado (PNMPO), instituído pela Lei $\mathrm{n}^{0} 11.110$, de 2005. Foi autorizado pelo Manual de Crédito Rural que, na operacionalização dos financiamentos do microcrédito produtivo rural orientado, os agentes financeiros, na interação com o público alvo, pudessem atuar por mandato, por intermédio de O rganizações da Sociedade Civil de Interesse Público (O scip) e de cooperativas singulares de crédito com seus assessores de crédito. Essa medida buscou estimular que outros agentes financeiros, além do Banco do Nordeste, que já atua dessa forma com o Agroamigo, desenvolvam parcerias com O scips e cooperativas de crédito para a aplicação do Pronaf Grupo B, a partir de uma metodologia de crédito orientado.

\section{O Pronaf Grupo B em números}

D esde sua criação, as contratações do Pronaf Grupo B cresceram quase continuamente a cada ano agrícola (Tabela 3). A partir da safra 2003/ 2004 alcançou-se um novo patamar de contratações, saindo dos cerca de 150 mil para mais de $300 \mathrm{mil}$ contratos, representando um crescimento superior a 100\%. Uma nova expansão de operações se deu na última safra. Foram mais de 550 mil contratos de Pronaf Grupo B em todo o Brasil no ano agrícola de 2005/2006, com 95\% deles concentrados no Nordeste.

Desde a criação do Pronaf Grupo B, mais de 1,5 milhão de contratos foram 
Tabela 3: Aplicações do Pronaf Grupo B por Plano de Safra

\begin{tabular}{l|c|l}
\hline Safras & Contratos & \multicolumn{2}{|l}{ Valorfinanciado } \\
\hline $2000 / 2001$ & 52.442 & $\mathrm{R} \$ \quad 26.076 .567,96$ \\
\hline $2001 / 2002$ & 154.481 & $\mathrm{R} \$ \quad 77.110 .900,13$ \\
\hline $2002 / 2003$ & 139.760 & $\mathrm{R} \$ \quad 69.838 .802,76$ \\
\hline $2003 / 2004$ & 333.555 & $\mathrm{R} \$ 327.010 .055,39$ \\
\hline $2004 / 2005$ & 358.456 & $\mathrm{R} \$ 358.593 .958,49$ \\
\hline $2005 / 2006$ & 553.555 & $\mathrm{R} \$ 555.347 .460,85$ \\
\hline Total & 1.592 .249 & $\mathrm{R} \$ 1.413 .977 .745,57$ \\
\hline
\end{tabular}

Fonte: SAF/MDA

firmados, envolvendo R \$ 1,4 bilhão. Mas ainda há um grande número de famílias que poderiam ser incluídas no crédito, considerando-se que o total de estabelecimentos com famílias do Grupo B, estimados com base no Estudo FAO/ Incra do Censo Agropecuário de 1995/ 1996, ultrapassava o contingente de dois milhões de famílias, dois terços destas na Região Nordeste.

Como mostra a Tabela 4, para a safra 2005/ 2006, o Banco do Nordestecontinuou sendo o principal aplicador da linha. Os números atestam ainda como é bastante tímidaa participação do Banco da Amazônia e do Banco do Brasil no total das aplicações.

Ainda assim, todas as regiões registraram operações na safra 2005/ 2006 (Tabela 5). D epois do Nordeste, o maior número de contratos estava na Região
Sudeste, especialmente em Minas Gerais, onde tanto o Banco do Brasil quanto o Banco do Nordeste atuam ${ }^{19}$. Já as regiões Centro-O este e Sul registraram os mais baixos desempenhos, com uma cobertura estimada de apenas 1\% dos estabelecimentos $\mathrm{G}$ rupo B potenciais.

A ampliação das fontes de recursos do Pronaf Grupo B foi fundamental para garantir a expansão das contratações e atender ao forte crescimento da demanda por esse crédito, após o processo de simplificação do acesso e o início da operação de outros agentes financeiros. Como mostra a Tabela 6, o crescimento das contratações do Banco do Nordeste somente é possível com o maior comprometimento de recursos do Fundo Constitucional de Financiamento do Nordeste (FNE) com esse crédito. Atualmente, o FNE é a

\section{Tabela 4: Participação dos Bancos nas aplicações - Safra 2005/ 2006}

\begin{tabular}{l|c|c|c|c}
\hline Bancos & Contratos & Valor Financiado & \% contratos & \% Valor \\
\hline BASA & 6.691 & $\mathrm{R} \$ 7.318 .881,88$ & $1,21 \%$ & $1,32 \%$ \\
\hline BB & 20.874 & $\mathrm{R} \$ 20.682 .212,26$ & $3,77 \%$ & $3,72 \%$ \\
\hline BNB & 525.990 & $\mathrm{R} \$ 527.346 .366,71$ & $95,02 \%$ & $94,96 \%$ \\
\hline Total & 553.555 & $\mathrm{R} \$ 555.347 .460,85$ & $100,00 \%$ & $100,00 \%$ \\
\hline
\end{tabular}

Fonte: SAF/MDA 
Tabela 5: Participação das regiões nas aplicações do Pronaf Grupo B Safra 2005/ 2006

\begin{tabular}{|c|c|c|c|c|c|c|}
\hline Regiones & $\begin{array}{c}\text { Estabelecimentes } \\
\text { FAO/INCRA }\end{array}$ & Cobernum $(\%)^{*}$ & $\begin{array}{c}\text { Safra } \\
2005 / 2006\end{array}$ & $\begin{array}{l}\text { Todas } \\
\text { as safrax }\end{array}$ & $\begin{array}{c}\text { W Safin } \\
2005 / 2006\end{array}$ & $\begin{array}{l}\text { \% Todas } \\
\text { as safras }\end{array}$ \\
\hline Sul & 165.1091 & $0,54 \%$ & 894 & 2265 & $0, t 6 N_{3}$ & 0,1476 \\
\hline Suknente & 198.382 & $2 \times, 00 \%$ & 55.536 & 158.369 & $100 \%$ & 9,959 \\
\hline Noete & 1.33740 & $6,39 \%$ & 8,551 & 42.412 & $1,34 \%$ & 2,0094 \\
\hline Noedkste & 1.439 .537 & $32,57 \%$ & 488.465 & 1.385478 & $88.24 \%$ & $87,23 \%$ \\
\hline Centro-Oeste & 32031 & $0,32 \%$ & 127 & 207 & $0 / 0 \%$ & $0,01 \%$ \\
\hline Sem Informingly & & & & in & Bjars & $0,0 \% n$ \\
\hline Toes Glohal & 2016.641 & $27,19 \%$ & 553.555 & 1592249 & $100,00 \%$ & to00kr: \\
\hline
\end{tabular}

* Cobertura, calculada pela divisão do número de contratos na safra 2005/ 2006 pelo total de estabelecimentos estimados com base no Estudo FAO/Incra.

principal fonte de recursos do Pronaf G rupo B, representando 94\% dos recursos aplicados na última safra. A participação do Fundo Constitucional de Financiamento do Norte (FNO) ainda é muito tímida, respondendo por menos de $1 \%$ dos recursos aplicados. Já os recursos do Tesouro Nacional, que antes representavam $100 \%$ do valor financiado, significaram, na safra 2005/ 2006, apenas $6 \%$ do total aplicado. Adicionalmente, o MDA continua buscando uma solução para 0 início da operacionalização da linha com os recursos do Fundo Constitucional de Financiamento do Centro O este (FCO).

\section{Pronaf Grupo B: lições aprendidas e novos desafios}

O microcrédito produtivo tem sido considerado um importante instrumento para a redução da pobreza. Criado em
2000, o crédito Grupo B do Pronaf nasceu da necessidade de se buscar trabalhar de forma diferenciada com a agricultura familiar de mais baixa renda do meio rural, a qual se estimava em torno de dois milhões de estabelecimentos, metade destes concentrados no Nordeste.

Inicialmente com pouco mais de 50 mil operações na safra 2000/ 2001, essa linha alcançou, na safra 2005/ 2006, um acumulado de cerca de 1,6 mil contratos e R \$ 1,4 bilhão em empréstimos, configurando, assim, o maior programa de microcrédito produtivo rural do País.

Alcançar o público de mais baixa renda do campo, por meio de um programa cujo arranjo institucional se insere no Sistema Nacional de Crédito Rural (SNCR), é uma opção que resulta em ganhos e perdas. Integrada ao SNCR, qualquer alteração mínima de regras está sujeita a uma formalização ea recorrentes negociações via

Tabela 6: Participação de cada fonte do Pronaf Grupo na safra 2005/ 2006

\begin{tabular}{l|l|l|r|l}
\hline Safra 2005/2006 & FNE & FNO & OGU & \multicolumn{1}{l}{ Total } \\
\hline Valores financiados & RS 521.444,755,44 & RS 795,273,92 & RS $33,107,431,49$ & RS $555,347,460,85$ \\
\hline Participaclio (\%) & $93,9 \%$ & $0,1 \%$ & $6,0 \%$ & $100,0 \%$ \\
\hline
\end{tabular}

Fonte: SAF/MDA 
Conselho Monetário Nacional, despendendo pelo menos um mês para ser aprovada. Adicionalmente, um crédito de $\mathrm{R} \$ 1,5$ mil sujeito a um mesmo normativo que rege valores acima de $\mathrm{R} \$ 200 \mathrm{mil}$, como na agricultura de maior porte, exige constante esforço de adaptação e de criação, no Manual de Crédito Rural, de uma série de procedimentos operacionais específicos, como proposta simplificada em vez de projetos de crédito, garantia apenas pessoal suficiente para alguns grupos, possibilidade de aplicação no rural não agrícola, fiscalização por amostragem, laudos simplificados, risco não bancário.

No SNCR, o Grupo B do Pronaf integra parte da política de crédito produtivo rural do País, deixando de ser apenas uma ação orçamentária executada por agências especiais de governo com baixa capilaridade. Conseqüentemente, passa a poder disputar as fontes asseguradas ao crédito rural - Fundos Constitucionais de Financiamento, recursos orçamentários etc. - e, sobretudo, a dispor dos agentes financeiros públicos federais como principais operadores, que, presentes em quase todos os municípios do Brasil, conferem maior alcance e porte nacional ao Programa.

Ao longo dos sete anos de história do Pronaf Grupo B, muitas foram as mudanças. Inicialmente a linha atuou apenas no Nordeste por empenho do BNB. Nesse período, a operacionalização do crédito incidiu sobre um forte movimento de mobilização da sociedade civil organizada, com participação obrigatória dos Conselhos Municipais de D esenvolvimento Rural (CMDR), que deliberaram as propostas apresentadas ao banco. As safras 2000/ 2001 e 2001/ 2002 constituíram-se em períodos de grande aprendizado para todos os envolvidos e evidenciaram mais fortemente os principais entraves advindos de um modelo de operacionalização de crédito com as mesmas exigências burocráticas tanto para o financiamento de uma proposta de R\$ 1 mil quanto para um financiamento cerca de 100 vezes maior.

Assim, a terceira Safra do Pronaf Grupo $B$ elegeu 0 combate à excessiva burocratização do acesso ao crédito como alvo de atuação, iniciando um processo de simplificação das exigências ao tomador - garantias, títulos de propriedade, comprovantes de aplicação - , o qual incluiu ainda a desobrigação da participação dos CMD R, sendo este entendido como entrave para alcançar outras regiões do País onde não haviam sido formados. Todas essas alterações geraram resultados, as contratações bateram recorde na safra 2003/ 2004 e os custos da aplicação da linha foram reduzidos, encorajando o início da aplicação do Pronaf Grupo B pelo Banco da Amazônia e, conseqüentemente, a participação das famílias de baixa renda da Região Norte do País.

Maior facilidade de acesso e possibilidade de atuação em todo o meio rural brasileiro, com a introdução do Grupo B na carteira do Banco do Brasil, resultou em contratações crescentes e, por conseguinte, em pressão por mais recursos para financiamento. A safra 2004/ 2005 assumiu como principal desafio a busca de novas fontes de recursos. Estas, por sua vez, teriam que dispor de características especiais, como manter a isenção do risco bancário, condição até então fundamental para contar com a participação dos bancos públicos federais na aplicação da linha. A solução foi encontrada por meio da participação dos Fundos Constitucionais de Financiamento, que passaram a constituir a principal fonte de recursos da linha, diminuindo a utilização dos recursos orçamentários para essa função. 
D esburocatizado 0 acesso, conquistadas novas fontes e novos agentes operadores, a safra 2005/2006 iniciou uma nova abordagem no aperfeiçoamento do Pronaf Grupo B. Tratou-se, então, de pensar no desenvolvimento de metodologia específica de oferta desse crédito, capaz de transformá-lo de crédito "micro" em "microcrédito". As mudanças nas regras de acesso objetivam conferir maior flexibilidade e adaptabilidade dos valores financiados às reais necessidades do tomador. Uma experiência de oferta orientada desse microcrédito tem início no Banco do Nordeste, sendo intitulada de Agroamigo.

A safra 2006/ 2007 dá continuidade a essa transformação do crédito Pronaf Grupo B em microcrédito rural assistido. Convênios da SAF com empresas estaduais de ATER, no âmbito da política nacional de ATER, exigem a prestação de serviços junto a esse público como contrapartida para recebimento de recursos. A parceria com o BNB é reforçada, esperando-se, ao final de 2007, que todas as operações de Grupo B do Pronaf possam ser realizadas segundo a nova metodologia. Consolidada a operacionalização do Grupo B pelo Agroamigo, a perspectiva de médio prazo indica que esses assessores comecem a atuar com 0 Grupo C, facilitando, assim, a transição das famílias agricultoras entre os dois G rupos. Além disso, busca-se maior articulação da linha de crédito com outros programas que têm esse público como alvo, tal qual 0 Programa Nacional de Biodiesel e o Programa Bolsa-Família, iniciando-se, dessa maneira, um esforço de articulação e potencialização de políticas públicas.

O bserva-se, então, que a construção de uma política pública de microcrédito produtivo para as famílias de mais baixa renda no meio rural é possível e tem acontecido em etapas. Ao longo dessa trajetória, nem todos os passos são passíveis de avaliação com profundidade, mas alguns aprendizados dessa experiência já poderiam ser sistematizados para servir de reflexão à construção e ao aprimoramento de outras políticas públicas. Diante disso, merecem destaque quatro pontos:

1) O perar microcrédito rural, no âmbito do SNCR, assegura um maior porte (bancos operando em todo o País) e institucionalidade ao Programa (inserido na política de crédito rural do País e contando, portanto, com uma base legal consolidada), que deve ser equilibrado com constantes adaptações do normativo às especificidades do público de mais baixa renda;

2) Trabalhar com os grupos mais descapitalizados de agricultores exige condições diferenciadas de financiamento (juros, valores, composição do risco) e algum nível de subsídio capaz de encorajar a tomada de financiamento por famílias que nunca tomaram empréstimos e se motivam com a possibilidade de cumprir, com facilidade, o seu pagamento, ou mesmo pela opção de rápida capitalização de sua atividade produtiva por meio de descontos iniciais no pagamento das parcelas em dia;

3) Fazer com que agentes financeiros - os quais privilegiam majoritariamente a ótica econômica nos critérios de concessão de financiamento - trabalhem com um grupo da população excluída do sistema financeiro bancário exige uma engenharia de risco específica. Isentar os agentes financeiros do risco das operações com os Grupos de mais baixa renda, quando esses primeiros não dispõem de metodologia de acesso não bancário à informação sobre esse público, tem-se mostrado a única forma de fazê-los operar 
a linha de crédito e, ao mesmo tempo, iniciar uma relação desse público com 0 agente financeiro, permitindo, assim, uma inserção posterior em linhas de risco bancário;

4) Asseguradas fontes de financiamento e avançada a simplificação do acesso ao crédito, a metodologia de oferta passa a ser 0 elemento fundamental para que o Pronaf Grupo B seja mais bem aplicado e a relação famílias e agentes financeiros fortalecida. A experiência com o Agroamigo do BNB tem mostrado que, com orientação, as possibilidades de aplicação dos recursos se ampliam (atividades não agrícolas passam a ser financiadas), 0 tempo das contratações e renovações diminui, a inadimplência cai, novas famílias são incluídas, e as possibilidades de ascensão ao Pronaf $\mathrm{C}$ aumentam.

Em suma, os desafios de transformar a linha de crédito Pronaf Grupo B em um instrumento de microcrédito produtivo orientado capaz de auxiliar no combate à pobreza rural ainda são muitos, e a estratégia para superá-los exige etapas. As dificul- dades, contudo, têm sido vencidas passo a passo. Em um esforço de eleger apenas dois focos principais de atuação para o Pronaf Grupo B nas próximas safras, merecem ser citados a expansão das experiências de oferta do crédito de forma orientada e 0 aperfeiçoamento dos mecanismos de monitoramento e avaliação dalinha. Nesse sentido, diversas conversas foram iniciadas recentemente com o Banco da Amazônia em prol de uma proposta de nova metodologia de aplicação, e, junto ao Banco do Brasil, atestam-se avanços por meio da metodologia do D esenvolvimento Regional Sustentável (DRS). No campo da melhoria dos instrumentos de gestão da linha, pode-se destacar 0 aperfeiçoamento das trocas de informações da SAF/ MDA com os agentes financeiros, assim como o investimento em estudos específicos com informações mais aprofundadas sobre o funcionamento e 0 impacto da linha Pronaf Grupo B junto aos tomadores do crédito. A caminhada continua.

(Artigo recebido em novembro de 2008. Versão final em junho de 2008).

\section{Notas}

${ }^{1}$ Instituídos pelo D ecreto n 3.508, de junho de 2000, eram condição obrigatória para o recebimento dos recursos do Pronaf Infra-Estrutura, repassados aos municípios para construção de obras que promovessem o desenvolvimento rural da localidade. Não se constituíam operações de crédito rural, mas convênios com prefeituras operacionalizados via Caixa Econômica Federal. A tualmente, o que era até então conhecido como Pronaf Infra-Estrutura foi reformulado e atua dentro de uma abordagem de desenvolvimento territorial, estando a cargo da Secretaria de D esenvolvimento Territorial do Ministério do D esenvolvimento Agrário.

${ }^{2}$ Manifestação Nacional coordenada pela Confederação Nacional dos Trabalhadores naAgricultura (Contag) e pelo D epartamento Nacional dos Trabalhadores Rurais daCentral Única dos Trabalhadores (D NTR/ CUT) existente até os dias de hoje e que, anualmente, no mês de maio, é realizada em Brasília, na Esplanada dos Ministérios. Nessa ocasião são apresentadas, por esse segmento da sociedade civil organizada, as demandas de melhorias nas políticas públicas da agricultura familiar para a safra seguinte. Adicionalmente, também no primeiro semestre de cada ano, outros movimentos 
da sociedade civil organizada do meio rural apresentam ao G overno, por meio de intensa mobilização na capital federal, suas pautas para próxima safra.

${ }^{3}$ Vale lembrar que mesmo o Pronaf tendo sido criado em 1996, somente em 2006, por meio da Lei no 11.326, definiu-se o conceito de agricultura familiar e a necessidade de formulação de políticas públicas específicas voltadas para esse público.

${ }^{4}$ Especial destaque nessa fase deve ser dado a Confederação Nacional dos Trabalhadores na Agricultura (Contag) eao D epartamento Nacional dos Trabalhadores Rurais da Central Única dos Trabalhadores (DNTR-CUT).

${ }^{5}$ Em sua concepção original, de 1996, o Pronaf desenvolvia quatro linhas de ação: 1) negociação de políticas públicas com órgãos setoriais; 2) financiamento da infra-estrutura e serviços nos municípios; 3) financiamento da produção da agricultura familiar; 4) capacitação e profissionalização de agricultores familiares e suas famílias. A tualmente novas linhas de ação foram adicionadas e outras redefinidas.

${ }^{6}$ Entende-se como renda bruta aquela obtida no ano agrícola anterior, sem os descontos dos custos de produção. Também não é computado, para fins de cálculo de renda de enquadramento, os proventos vinculados a benefícios previdenciários decorrentes de atividades rurais, nem tão pouco as transferências diretas de renda tal qual o Bolsa-Família.

${ }^{7}$ Importante mencionar que, no conceito de agricultura familiar empregado para fins de operacionalização do crédito Pronaf, é comum a todos os Grupos o cumprimento de um conjunto de características gerais: 1) explorar parcela deterra na condição de proprietário, posseiro, arrendatário, parceiro ou concessionário do Plano Nacional de Reforma A grária; 2) residir na propriedade ou em local próximo; 3) não dispor, a qualquer título, de área superior a 4 (quatro) módulos fiscais, quantificados segundo a legislação em vigor; 4) ter o trabalho familiar como predominante na exploração do estabelecimento, podendo manter até 2 (dois) empregados permanentes, admitida ainda a eventual ajuda de terceiros, quando a natureza sazonal da atividade 0 exigir.

${ }^{8}$ A partir da safra 2004/ 2005 os Fundos Constitucionais de Financiamento, quando funcionam como fonte para operações com esses grupos, também assumem o risco dessas aplicações, isentando os bancos gestores desses fundos do risco.

${ }^{9}$ E ntre as instituições ligadas aos movimentos rurais atualmente credenciados para emissão de DAP em vigor, estão a Associação Nacional dos Pequenos Agricultores (Anpa), Confederação Nacional dos Trabalhadores na A gricultura (Contag) e a Federação dos Trabalhadores na A gricultura Familiar (Fetraf).

${ }^{10}$ Nessa época, para enquadramento no G rupo B era exigida renda bruta familiar anual de até R\$ 1.500 e não existia o G rupo E do Pronaf. Esses condicionantes da época, entretanto, não tenderiam a gerar grandes distorções nas informações, constituindo-se o público do grupo B o mais expressivo da agricultura familiar, especialmente do Nordeste.

${ }^{11}$ No crédito agrícola não se trabalha com ano civil, mas sim com o período de safra agrícola, 0 qual compreende os 12 meses que vão desde a preparação da terra para o plantio até a colheita e comercialização da produção das principais safras do País. No Brasil, a safra agrícolainicia-se em $1^{\circ} \mathrm{de}$ julho de um ano e termina em 30 de junho do ano seguinte. É a partir de julho que se concentra a maior parte do plantio da Região Centro Sul, principal produtora agrícola do País. Anualmente, 0 Ministério da Agricultura e o Ministério do D esenvolvimento Agrário lançam, separadamente, os seus Planos de Safra, compostos pelo conjunto de ações, entre elas as linhas de crédito rural, que são disponibilizadas pelo Governo para apoio da safra daquele ano. Em razão disso, as principais alterações nos normativos de crédito são submetidas ao Conselho Monetário Nacional no primeiro semestre do ano. 
12 O Secretário Executivo Estadual do Pronaf era cargo criado e ocupado por pessoas do G overno Estadual, normalmente vinculado à Secretaria de Agricultura do Estado. Esse secretário deveria trabalhar com políticas de desenvolvimento da agricultura familiar. Recebia apoio, inclusive na forma de recursos, do Ministério do D esenvolvimento Agrário (MDA), para poder acompanhar e articular as ações do Pronaf no Estado. Muitos Estados ainda mantêm o cargo de Secretário Executivo Estadual da A gricultura Familiar. Porém, com a criação das D elegacias Federais do MDA em 2003, estas passaram a ser a principal instância de articulação, monitoramento e coordenação das ações do Pronaf e do Ministério nos Estados.

${ }^{13}$ No caso do Norte de Minas G erais, onde também atua o BNB, as contratações só começaram a ocorrer em dezembro de 2000.

${ }^{14}$ Essa situação está sendo agora resolvida pela Resolução nº 3.405, de 2006, que permite a liberação dos avalistas das operações do G rupo B contratadas até dezembro de 2005.

${ }^{15}$ A Constituição Federal de 1988 destinou 3\% do produto da arrecadação dos impostos sobre renda e proventos de qualquer natureza e sobre produtos industrializados para aplicação em programas de financiamento aos setores produtivos das Regiões Norte, Nordeste e Centro-O este, criandose assim os Fundos Constitucionais de Financiamento do Norte (FNO), do Nordeste (FNE) e do Centro-O este (FCO), geridos, respectivamente, pelo Banco da Amazônia, Banco do Nordeste e Banco do Brasil.

${ }^{16} \mathrm{~A} \mathrm{MP} \mathrm{n}^{0} 205$ foi posteriormente convertida na Lei $\mathrm{n}^{0} 11.011$.

${ }^{17}$ Essafoi uma mudança que ocorreu para todos os demais G rupos do Pronaf jána safra 2003/ 2004.

${ }^{18}$ No Bolsa Família, por exemplo, a renda máxima familiar permitida na época era de R $\$ 100,00$ per capita mensal, o que em uma família de 4 pessoas significaria algo próximo a $\mathrm{R} \$ 5$ mil anuais. D ado que os proventos de benefícios previdenciários rurais não contam para fins de cálculo de renda de enquadramento do Pronaf, mas sim para o caso do Bolsa Família, aceitou-se que o valor de $\mathrm{R} \$ 3$ mil de renda bruta anual familiar pela metodologia de cálculo do Pronaf pudesse ser uma boa equivalência para a renda familiar anual de $\mathrm{R} \$ 5$ mil do Bolsa Família.

${ }^{19} \mathrm{O}$ BNB atua no Norte de Minas G erais apenas, área de atuação da Adene - Agência de D esenvolvimento do Nordeste.

\section{Referências bibliográficas}

Bittencourt, G ilson Alceu. Abrindo a Caixa Preta: o financiamento da agricultura familiar no Brasil. D issertação apresentada ao Instituto de Economia da Unicamp. Campinas, SP, 2003.

FAo/ InCRa. Perfil da Agricultura Familiar no Brasil: dossiê estatístico. Brasília, 1996. Novo Retrato da Agricultura Familiar: o Brasil redescoberto. Brasília, 2000.

Manzon Neto. M. P. Impacto da Renda em microcrédito: uma investigação empírica sobre geração de renda do Crédito Popular Solidário (São Paulo Confia), no Município de São Paulo. Tese de doutorado apresentada a Fundação Getúlio Vargas, 2006 Ministério da Agricultura e do Abastecimento - MAA. Secretaria de Desenvolvimento Rural, Programa Nacional de Fortalecimento Familiar. Brasília: 1996. 
. Agricultura familiar, reforma agrária e desenvolvimento local com base na expansão da agricultura familiar e sua inserção no mercado. Brasília: MDA. 2000 MatTeI, Lauro. Impactos do Pronaf: análise de indicadores. Brasília: NEAD, 2005. Parente, Silvana. Microfinanças: saiba o que é um banco do povo. Brasília: Agência de Educação para o Desenvolvimento, 2002.

Silva, Enid Rocha Andrade. Programa Nacional de Fortalecimento daA gricultura Familiar - Pronaf: Uma Avaliação das Ações Realizadas no Período 1995/ 1998. Brasília/ DF, Ipea, 1999,

Toneto, Jr. R. e G renaud, A. P. Microcrédito e financiamento rural; recomendações de desenho e e gestão a partir da experiência mundial. Planejamento e Políticas Públicas, $\mathrm{n}^{0}$ 25, p. 89-104, jun-dez, 2002. 


\section{Anexo}

D escrição, para cada safra, das normas operacionais do Pronaf Grupo B e suas mudanças segundo critérios de enquadramento do(a) agricultor(a) familiar, condições de financiamento, operacionalização, fonte de recursos e agente financeiro operador.

\section{Safra 2000/ 2001}

\section{Enquadramento}

Renda bruta familiar anual de R $\$ 1,5$ mil proveniente do estabelecimento. Entendese como renda bruta aquela obtida no ano agrícola anterior, sem os descontos dos custos de produção. Também não é computado, para fins de cálculo de renda de enquadramento, os proventos vinculados a benefícios previdenciários decorrentes de atividades rurais.

\section{Condições de financiamento}

L imite: $\mathrm{R} \$ 500,00$ em até 3 operações.

Juros: $1 \%$ a.a

Benefício: bônus de adimplência de 40\% sobre cada parcela da dívida paga até a data de seu vencimento.

Prazo: até 2 anos, até 1 ano de carência.

$\mathrm{G}$ arantias: as do crédito rural, de livre negociação entre mutuário e agente financeiro.

\section{O peracionalização}

DAP - D eclaração de Aptidão do Pronaf, emitida e assinada, conjunta e obrigatoriamente, pelo Sindicato e pela Empresa de Assistência Técnica e Extensão Rural ATER.

Publicação de Portaria do Ministério do Desenvolvimento Agrário estabelecendo modelo de proposta simplificada de crédito e o manual de operacionalização do Pronaf G rupo B, o qual atribui aos Conselhos Municipais de D esenvolvimento Rural Sustentável (CMD RS) ou ao Conselho Estadual de D esenvolvimento Rural (CED RS), quando aquele não existir, a atribuição de analisar e encaminhar ao agente financeiro as propostas de crédito do Grupo B.

\section{Fonte de Recursos}

Tesouro Nacional.

\section{Agente Financeiro Operador}

Banco do Nordeste. 


\section{Safra 2001/ 2002}

\section{E nquadramento}

Renda bruta familiar anual de R \$ 1,5 mil proveniente do estabelecimento. Entende-se como renda bruta aquela obtida no ano agrícola anterior, sem os descontos dos custos de produção. Também não é computado, para fins de cálculo de renda de enquadramento, os proventos vinculados a benefícios previdenciários decorrentes de atividades rurais.

\section{Condições de financiamento}

A lteração no prazo de reembolso: até 1 (um) ano, incluídos até 6 (seis) meses de carência, podendo o reembolso estender-se em até dois anos, quando o cronograma da atividade assim 0 exigir.

\section{O peracionalização}

Formalização, dentro do manual de crédito rural (MCR), da substituição, no caso do Pronaf B, do projeto técnico pela proposta de crédito simplificada, apresentada em formulário específico e padronizado, fornecido pelo Ministério do Desenvolvimento Agrário.

\section{Fonte de Recursos}

Tesouro Nacional.

\section{Agente Financeiro Operador}

Banco do Nordeste.

\section{Safra 2002/ 2003}

\section{E nquadramento}

Renda bruta familiar anual de R \$ 1,5 mil proveniente do estabelecimento. Entende-se como renda bruta aquela obtida no ano agrícola anterior, sem os descontos dos custos de produção. Também não é computado, para fins de cálculo de renda de enquadramento, os proventos vinculados a benefícios previdenciários decorrentes de atividades rurais.

\section{Condições de financiamento}

Retorno ao prazo de até 2 anos com até 1 ano de carência.

\section{Operacionalização}

Formalização, dentro do MCR, o mecanismo de gestão social na operacionalização do crédito, estabelecendo-se que as propostas de crédito devem ser reunidas e encaminhadas aos agentes financeiros pelo:

a) Conselho Municipal de Desenvolvimento Rural Sustentável (CMDRS).

b) Conselho Estadual de D esenvolvimento Rural Sustentável (CED RS), quando de interesse de pescadores artesanais, remanescentes de quilombos e extrativistas, localizados em municípios que ainda não dispõem do CMDRS. 


\section{Fonte de Recursos}

Tesouro Nacional.

\section{Agente Financeiro Operador}

Banco do Nordeste.

\section{Safra 2003/ 2004}

\section{Enquadramento}

Ampliação do valor bruto anual familiar de enquadramento para $\mathrm{R} \$ 2$ mil.

\section{Condições de financiamento}

A mpliação do limite: R\$ 1 mil e máximo de até 3 operações.

A lteração do Benefício: bônus de adimplência de $25 \%$ sobre cada parcela da dívida paga até a data de seu vencimento.

Indusão de percentual financiável de A TE R: até 3\% do valor do financiamento podem ser destinados à remuneração de assistência técnica.

\section{Operacionalização}

Portaria da SAF/ MDA institui os CEDRS como credenciadores das empresas de ATER para o Grupo B.

\section{Fonte de Recursos}

Tesouro Nacional.

\section{Agente Financeiro Operador}

Banco do Nordeste, Banco da Amazônia (05/ 2004, após a aprovação das medidas de simplificação). acesso)

Resolução no 3.150, de novembro de 2003 (medidas de simplificação do

\section{E nquadramento}

Ampliação do valor bruto anual familiar de enquadramento para $\mathrm{R} \$ 2$ mil.

\section{Condições de financiamento}

Respaldo legal aos agentes financeiros operadores no que concerne a $\mathrm{G}$ arantias, que poderá ser apenas a garantia pessoal do proponente.

\section{Operacionalização}

Fim da obrigatoriedade de mediação dos Conselhos na operacionalização do crédito mantendo-se 0 cadastramento da ATER no CEDRS. As propostas de crédito podem ser encaminhadas ao agente financeiro sem passar, obrigatoriamente, pelo CED RS ou CMD RS. 
DAP passa a ser instrumento suficiente para comprovar a relação do beneficiário com a terra e a atividade objeto de financiamento, não sendo mais exigido título de propriedade ou contrato de arrendamento registrado em cartório.

D esburocratização do acesso aos recursos com a dispensa de apresentação dos comprovantes relativos aos bens adquiridos, exceto quando referentes a máquinas, equipamentos, embarcações e veículos financiados nas modalidades de crédito grupal ou coletivo, de valor superior a R $\$ 5$ mil, situação em que devem ser entregues ao financiador no prazo de até 30 dias a contar da liberação.

\section{Fonte de Recursos}

Tesouro Nacional.

\section{Agente Financeiro 0perador}

Banco do Nordeste, Banco da Amazônia.

\section{Safra 2004/ 2005}

\section{Enquadramento}

Mínimo de 30\% da renda familiar bruta anual de enquadramento, oriunda da exploração agropecuária e não agropecuária do estabelecimento. Inclui-se assim famílias que vendem sua mão de obra a terceiros ou desenvolvem atividades geradoras de renda fora do estabelecimento, como estratégia de sobrevivência.

\section{Condições de financiamento}

Instituição de que a garantia da operação deverá ser apenas a garantia pessoal do proponente.

\section{O peracionalização}

Facilidade de acesso à DAP e conseqüente diminuição dos custos de transação envolvidos na sua obtenção. A DAP do Grupo B exige apenas a assinatura da instituição emitente: sindicato ou empresas de ATER.

Em novembro de 2004 é assinado Termo de Cooperação Técnica entre o Ministério do Desenvolvimento Agrário (MDA) e Banco do Nordeste do Brasil (BNB), para desenvolvimento de nova metodologia de oferta de crédito: o Agroamigo.

\section{Fonte de Recursos}

Ampliação das fontes de recursos, inclusão dos Fundos Constitucionais de Financiamento (MP 205 de agosto de 2004, convertida na Lei 11.011).

\section{Agente Financeiro Operador}

Banco do Nordeste, Banco da Amazônia, Banco do Brasil (09/ 2004). 


\section{Safra 2005/ 2006}

\section{E nquadramento}

Mínimo de 30\% da renda familiar bruta anual de enquadramento, oriunda da exploração agropecuária e não agropecuária do estabelecimento. Inclui-se assim famílias que vendem sua mão de obra a terceiros ou desenvolvem atividades geradoras de renda fora do estabelecimento, como estratégia de sobrevivência.

\section{Condições de financiamento}

É criada uma seção específica para o Pronaf Grupo B dentro do capítulo do Pronaf no Manual de Crédito Rural. Pela primeira vez o Pronaf B passa a ser referido nos normativos como microcrédito produtivo rural.

Nova forma de acesso aos recursos fixa limite máximo a ser acessado por família, mas flexibiliza para além de 3 o número de operações que podem ser realizadas até atingir esse teto.

L imites: até R \$ 3 mil por família beneficiada, independente do número de operações, sendo que:

I) cada financiamento não pode ultrapassar o valor de $\mathrm{R} \$ 1$ mil;

II) o segundo e demais financiamentos só podem ser realizados caso sejam quitados os débitos dos financiamentos anteriores;

III) 0 crédito deve ser liberado em parcelas, de acordo com o cronograma de aplicação dos recursos, facultado ao agente financeiro, independentemente do referido cronograma, efetuar a liberação do crédito em parcela única, objetivando a racionalização do processo e a redução de custos para o mutuário.

Prazo: até 2 anos, sem fixação de prazos de carência.

A mpliação das finalidades: financiamento das atividades agropecuárias e nãoagropecuárias desenvolvidas no estabelecimento rural ou em áreas comunitárias rurais próximas, assim como implantação, ampliação ou modernização da infra-estrutura de produção e serviços agropecuários e não-agropecuários, observadas as propostas ou planos simples específicos, entendendo-se por prestação de serviços as atividades não-agropecuárias como, por exemplo, o turismo rural, produção de artesanato ou outras atividades que sejam compatíveis com o melhor emprego da mão-de-obra familiar no meio rural, podendo os créditos cobrir qualquer demanda que possa gerar renda para a família atendida.

\section{Operacionalização}

Ampliação dos valores dispensados para apresentação dos comprovantes relativos aos bens adquiridos, exigido apenas quando referentes a máquinas, equipamentos, embarcações e veículos financiados nas modalidades de crédito grupal ou coletivo, de valor superior a R 10 mil, situação em que devem ser entregues ao financiador no prazo de até 30 dias a contar da liberação.

Instituição de capacidade de gestão e monitoramento do crédito estabelecendo-se que a linha de crédito do Grupo "B" do Pronaf será operacionalizada pelos agentes 
financeiros em comum acordo com a Secretaria de Agricultura Familiar do Ministério do D esenvolvimento Agrário, no que diz respeito ao estabelecimento de cotas estaduais de distribuição de recursos, limites municipais de contratação, limites de taxas de inadimplência, para fins de suspensão das operações nos municípios e critérios para retomada das operações, entre outros.

\section{Fonte de Recursos}

Ampliação das fontes de recursos, inclusão dos Fundos Constitucionais de Financiamento (MP nº 205 de agosto de 2004, convertida na Lei $n^{0} 11.011$ ).

\section{Agente Financeiro Operador}

Banco do Nordeste, Banco da Amazônia, Banco do Brasil (09/ 2004).

\section{Safra 2006/ 2007}

\section{Enquadramento}

Elevação da renda familiar bruta anual de enquadramento para até R\$ 3 mil.

\section{Condições de financiamento}

Ampliação das possibilidades de aplicação produtiva do Crédito.

Finalidades: financiamento das atividades agropecuárias e não-agropecuárias desenvolvidas no estabelecimento rural ou em áreas comunitárias rurais próximas, assim como implantação, ampliação ou modernização da infra-estrutura de produção e serviços agropecuários e não-agropecuários; observadas as propostas ou planos simples específicos, entendendo-se por prestação de serviços as atividades não-agropecuárias como, por exemplo, o turismo rural, produção de artesanato ou outras atividades que sejam compatíveis com o melhor emprego da mão-de-obra familiar no meio rural, podendo os créditos cobrir qualquer demanda que possa gerar renda para a família atendida, sendo:

I) permitida a sua utilização nas diversas atividades listadas na proposta simplificada de crédito;

II) facultado ao mutuário utilizar o financiamento em todas ou em algumas das atividades listadas na proposta simplificada de crédito sem efetuar aditivo ao contrato.

A mpliação do limite: R\$ 1,5 mil, independentemente do número de operações, observado que:

I) o somatório dos financiamentos concedidos a famílias de agricultores desse grupo, com direito a bônus de adimplência, não excederá $\mathrm{R} \$ 4$ mil;

II) alcançado o limite de $\mathrm{R} \$ 1,5$ mil a concessão de novos créditos fica condicionada à prévia liquidação de financiamento anterior;

III) o crédito deve ser liberado em parcelas, de acordo com o cronograma de aplicação dos recursos.

Maior controle sobre a assistência técnica: até 3\% (três por cento) do valor do financiamento podem ser destinados à remuneração de assistência técnica, quando julgada necessária e desde que haja concordância explícita do mutuário. 
Garantia de acesso ao crédito B sem limite no número de operações. Os agricultores que já atingiram o teto operacional de $\mathrm{R} \$ 4$ mil com direito a bônus de adimplência, caso comprovem que continuam enquadrados no G rupo "B", mediante apresentação da "D eclaração de Aptidão ao Pronaf (DAP)" ao agente financeiro, ficam habilitados a novos créditos nesse G rupo, nas mesmas condições dessa seção, exceto quanto ao bônus de adimplência, que nessa hipótese não mais será aplicado.

Indusão das famílias no Programa de Biodiesel: pode ser concedido financiamento de custeio agrícola, exclusivamente para a cultura da mamona, solteira ou consorciada, a agricultores que explorem a cultura em regime de parceria ou integração com indústrias de biodiesel, desde que observados as datas de plantio e os municípios recomendados no Zoneamento Agrícola de risco climático divulgado pelo Ministério da Agricultura, Pecuária e Abastecimento.

\section{Operacionalização}

A proximação com as políticas públicas de microcrédito orientado autorizando que na operacionalização dos financiamentos do microcrédito produtivo rural, realizados entre os agentes financeiros e os beneficiários finais, quando adotada a metodologia de microcrédito preconizada pelo Programa Nacional de Microcrédito Produtivo O rientado (PNMPO), instituído pela Lei 11.110, de 25/ 4/ 2005, os agentes financeiros, mantidas suas responsabilidades, possam atuar por mandato, por intermédio de Organizações da Sociedade Civil de Interesse Público (O scip) e cooperativas singulares de crédito, utilizando as fontes disponíveis e as condições financeiras estabelecidas para o microcrédito produtivo rural.

\section{Fonte de Recursos}

Ampliação das fontes de recursos, inclusão dos Fundos Constitucionais de Financiamento (MP 205 de agosto de 2004, convertida na Lei no 11.011).

\section{Agente Financeiro Operador}

Banco do Nordeste, Banco da Amazônia, Banco do Brasil (09/ 2004). 


\section{Resumo - Resumen - Abstract}

\section{Transformando burocracias para financiar os mais pobres: a evolução do Pronaf Crédito Grupo B \\ L etícia M endonça}

Instituições bancárias tradicionalmente não oferecem serviços financeiros, principalmente crédito produtivo, aos grupos de mais baixa renda. Considerando-se a rigidez do sistema financeiro em trabalhar com os mais pobres, o presente artigo descreve o processo de criação eaperfeiçoamento de uma política pública de microcrédito rural dentro do Programa Nacional de Fortalecimento da Agricultura Familiar (Pronaf). São apresentadas as motivações para alterações no desenho da linha de crédito, assim como as mudanças normativas, de fontes e de agentes operadores, efetuadas em cada ano-safra para tornar possível superar os desafios apresentados pela burocracia do Sistema Nacional de Crédito Rural - SNCR. 0 texto apresenta ainda o impacto no número de contratações resultante das diversas medidas tomadas. Finalmente, é feito um balanço das principais lições aprendidas assim como dos desafios atuais de maior qualificação do microcrédito e integração com outras políticas públicas.

Palavras-chave: políticas públicas; pobreza rural; microcrédito.

Transformando las burocracias para financiara los más pobres: la evolución del 'Pronaf crédito grupo B'

L etícia M endonça

Las instituciones bancarias no ofrecen tradicionalmente los servicios financieros a los grupos de bajo ingreso de la sociedad, especialmente el crédito productivo. Considerando la rigidez del sistema financiero en trabajar con los más pobres, el presente artículo describe el proceso de creación y implementación de una política pública de micro crédito rural del Programa Nacional de Fortalecimiento de laAgricultura Familiar (Pronaf). También, presenta las motivaciones para cambiar la línea de crédito, así como sus aspectos normativos, de fuentes y agentes operadores, efectuadas en cada año agrícola para tornar posible la superación de los desafíos presentados por la burocracia del Sistema Nacional de Crédito Rural. Todavía, el artículo presenta el impacto en el número de contrataciones como resultado de varias medidas realizadas. Finalmente, se hace una evaluación de las principales lecciones aprendidas así como de los desafíos actuales de mayor calificación del micro crédito y su integración con las demás políticas publicas.

Palabras clave: políticas públicas; pobreza rural; micro crédito.

Transforming bureaucracy to finance the poorest: the evolution of 'Pronaf crédito grupo B'

L etícia M endonça

Banking institutions traditionally do not offer financial services, especially productive credit to the low-income groups of society. Considering the rigid structure of the financial system in working with the poor ones, this article describes the process of the creation and the implementation of a rural micro credit public policy in the National Program of Assistance to Family Farms (Pronaf). It also presents motivational aspects to help changing the structure of the credit line, as well as the normative ones, including sources and operational agents in each agricultural year to make it possible overcome the challenges presented by the bureaucratic National Rural Credit System - SNCR. This 
article shows the impact in number of contracts resulting from various changes taken during the process. Finally, it demonstrates a balance of the major lessons learnt as well as updated challenges of major micro credit qualification and integration to other public policies.

Key words: public policies; rural poverty; micro credit

Letícia Mendonça

Economista, Especialista em Políticas Públicas e Gestão Governamental e Coordenadora de Crédito da SAF/ MDA. Contato: leticia.mendonça@mda.gov.br 